\title{
The Impact of Teaching Vocational Education Using Project-based Learning Strategy on Developing Critical Thinking Skills among 10th- Grade Students
}

\author{
Samira Falah Al-Khrisha, Vocational Education Teacher Ministry of Education, Sameerfalah4@gmail.com \\ Dr. Othman Nasser Mansour, Department of Administration and Curriculum Department, Faculty of \\ Educational Sciences, Middle East University, Omansour@meu.edu.jo
}

\begin{abstract}
The study aims to identify the impact of teaching vocational education using a project-based learning strategy on developing critical thinking skills among 10th-grade students. To achieve the aim of the study, the semi-experimental approach is factored in. The study is applied to a sample consisting of 6010 thgrade female students from Rajm Al-Shami Al-Gharbi Mixed Secondary School in Muwaqqar District, and it is distributed equally between the two groups as follows: a 30-student experimental group and 30-student control. To measure the pre and post-performance of the two study groups, a 21 -item critical thinking skills test is prepared in its final form .

The results of the study show a statistically significant difference between the arithmetic means of the degrees of the students of the experimental and control groups in the post-test of critical thinking skills (knowledge of assumptions, deduction, inference, evaluation of arguments) and the critical thinking skills as a whole in favor of the experimental group. The study recommends adopting a project-based learning strategy as a basic strategy in teaching most units of the vocational education subject for its suitability for most of the activities in the textbook's units.
\end{abstract}

Keywords: Project-based Learning Strategy, Critical Thinking skills, Vocational Education.

Received: $12.11 .2020 \quad$ Accepted: 06.12.2020 $\quad$ Published: 13.01.2021

\section{INTRODUCTION}

The contemporary era is characterized by the huge explosion of knowledge and rapid changes in all fields of life. Being a great challenge for educators, the need to considerably employ several modern educational methods and strategies to develop students' thinking, research, and criticism skills has emerged. The objectives of education are no longer limited to conveying information to students, but learning has become dependent on students themselves who are the focus of the educational process. Therefore, it is essential to find teaching strategies that encourage students to discover and build knowledge, motivates them to inquire and conduct pieces of research, and work individually or in collaborative groups so that communication, learning, and production take place effectively and positively.

Zaitoun (2007) indicates that educational and instructional goals and objectives continually vary and develop because of changing the requirements of society and its social, cultural, economic, and political conditions. In light of the ers's changes, its rapid developments, its fast transformations, its immediate expectations, and its future challenges, the strategies, methods, approaches, and models of modern science instruction vary depending on the change of perception to the nature of the learning and teaching process on the one hand, and the shift to the constructivist school on the other hand. Also, Omar (2013) shows that the project-based learning strategy is based on scientific foundations built on constructivism theory, as students build their knowledge by themselves through their experiences, and learn more when they participate in educational activities instead of receiving information negatively.

Abu Hija (2001) indicates the ideas advocated by John Dewey that the educational curricula should be developed in a manner compatible with the students 'purposes, needs, and desires and transformed into a practical, applied concept in the form of purpose or intentional projects related to students' lives. He emphasizes that the project-based learning strategy is based on the main idea, which is learning, by doing, and learning according to students' desires and needs for life. Besides, learning should be independently practiced, meaning that students are responsible for their learning and the teacher's role in this method is a guiding role when necessary. Likewise, Mari and Haila (2009) emphasize that the project-based learning strategy is an 
organized scientific method, aiming to link school instruction with the life that students live outside and inside the school together, and in other words, it aims to link the school environment with the social environment.

Saeedi and Balushi (2008) confirm several objectives for project-based learning that converge with the nature of science, including teamwork, the consensus requirement for knowledge adoption, the role of discussion in developing knowledge, and other objectives. Therefore, the project-based learning strategy is considered one of the strategies that support the main strategies in science education such as inquiry-based learning and learning cycle. Lashin (2009) emphasizes that the use of the project within the school curricula has a great impact on stimulating the learning process so that students can formulate and plan the project's objectives and organize implementation procedures to achieve those goals.

Importantly, the project-based learning strategy deepens students' learning and allows them to face complex and challenging problems closely related to daily life, develop their learning, and efficiently and effectively reach higher stages of thinking, analysis, and creation. This is consistent with what the 21st century is witnessing in terms of the existence of a clear interest by researchers, educators, psychologists in studying thinking, and developing its various skills. With that, we need thinking, creative and critical minds to find solutions to contemporary problems facing humanity. Zoubi (2014) points out that humans do not have critical thinking by nature as their skills are educated and need training sessions. In addition, critical thinking is not linked to a certain age, as every individual can do it according to the level of mental, sensory, conceptual, and abstract abilities .

In light of the educators 'assertion that the critical thinking does not come naturally to a person whose skills need training and education using modern teaching strategies that help in his development, as well as providing an educational environment that helps in active interaction, and increases motivation, achievement, cooperation and participation, the idea of conducting the current study crystallized to investigate the impact of teaching vocational education using project-based learning strategy on developing critical thinking skills among 10th-grade students.

\section{Problem of the Study}

Practically speaking, some educators and families underestimate the significance of the education subject, as it suffers from insufficient attention affecting the achievement of its outcomes despite its importance to students and society. Emphasis shall be placed on activating its real role of providing students with the knowledge, practical skills, and attitudes that enhance a positive outlook towards professions, which in turn supports economic and social growth, and contributes to the development of the societal structure. For example, when students reach the 10th grade of elementary education, they can determine their educational path, so the student who tends to agriculture joins the agricultural field and studies Agricultural Engineering at the University. In addition, the student who tends to industry joins the industrial field and studies Industrial Engineering at the University and so on. The project-based learning strategy is one of the most appropriate modern teaching strategies that are compatible with this role, which works to equip students with the 21stcentury skills of responsibility, self-learning, enhancing cooperative learning, communication skills, and dealing with others, and practicing thinking in general and critical thinking in particular.

Being a teacher in teaching vocational education, and conducting a survey of vocational education teachers in Muwaqqar District, it is noted that there is a clear weakness in the practical reality of teaching them, the lack of readiness of many labs, and the lack of materials and tools necessary to implement the activities and projects in the subject. It is also noticed that there is a shortcoming in the teaching of the vocational education subject, where the course activities are explained in the form of theoretical steps written on the board (the traditional method), leading to the separation of female students, poor achievement, and low levels of thinking for them. Khamis and Abu Hammoud (2018) recommend the necessity of reconsidering the experience of teaching vocational education and optimally preparing the educational workshops.

In an age marked by the explosion of knowledge, the traditional methods of dealing with knowledge are no longer sufficient to meet the needs of students, achieve their desires, satisfy their needs, and improve their attitudes, performance, and thinking in general and critical thinking in particular. Thinking is also viewed in untraditional ways of contributing to facing this challenge that we all live with. This study is an attempt to improve methods of teaching vocational education to achieve the aspired results, where developing the students' vocational awareness of the different professions helps them to acquire their tendencies, trends, and readiness to correctly select their future profession (Mahasneh, 2013). Against this, the problem of the study is to identify the impact of teaching vocational education using a project-based learning strategy on developing critical thinking skills among 10th-grade students. 
In light of the problem of the study, the following questions are formatted.

1. What is the impact of using the project-based learning strategy in teaching vocational education on developing the skill of knowledge of assumptions among $10^{\text {th }}$-grade students compared to the traditional method?

2. What is the impact of using the project-based learning strategy in teaching vocational education on developing the deduction skill of $10^{\text {th }}$-grade female students compared to the traditional method?

3. What is the impact of using the project-based learning strategy in teaching vocational education on developing the inference skill of $10^{\text {th }}$-grade female students compared to the traditional method?

4. What is the impact of using the project-based learning strategy in teaching vocational education on developing the skill of evaluation of arguments among $10^{\text {th }}$-grade students compared to the traditional method?

5. What is the impact of using the project-based learning strategy in teaching vocational education on developing critical thinking skills as a whole among the $10^{\text {th }}$-grade female students compared to the traditional method?

\section{Significance of the Study}

The significance of study is represented in providing information on the importance of project-based learning strategy and the mechanism of its use in teaching vocational education for male and female teachers, paying the attention of those involved in curriculum preparation and development to the importance of enriching them with activities specific to the project in a way that stimulates creativity, thinking and developing positive trends among students, taking into account their timing, teaching the different practical aspects of the subject of vocational education and coming up with industrial products that can be used educationally and financially, helping teachers, through their effective application of project-based learning, to discover the capabilities, skills, and creativity of students, especially those who are not inclined to the traditional and theoretical teaching methods and methods and specifically in the practical side of the subject and assisting students to form tendencies and trends towards a future profession and select their educational path.

\section{Limitations of the Study}

This study is limited to the $10^{\text {th }}$ - grade female students at Rajm Al-Shami Al-Gharbi Mixed Secondary School that belongs to the Education Directorate in Muwaqqar District. The study is limited to the second semester of the academic year 2019/2020. It is also limited to the Small Projects Unit (dairy processing) in the subject of vocational education for the $10^{\text {th }}$ grade. The generalization of the results of this study is determined by the validity and reliability of the study instrument. The results of the study can only be generalized to the adopted study population and its similar populations.

\section{Terms of the Study}

\section{Project-based learning strategy}

It is defined as group activities carried out by students in the Small Projects Unit (dairy processing) that go through multiple stages, starting with selecting the project and planning for it by specifying the work steps and providing the necessary materials and tools, and then implementing them to obtain industrial products such as yogurt, Labneh, and White Cheese. Then, these products are tested and evaluated, and this is done under the supervision and guidance of the teacher and providing the appropriate environment within the vocational education workshop.

\section{Critical thinking}

It is defined as a set of skills that students acquire (knowledge of assumptions, deduction, inference, evaluation of arguments) and is measured through the students' response to the test preparation in the current study, which consists of (21) items to help them to objectively analyze news, knowledge, and data so that they can distinguish between assumptions and instructions in a logically and clearly and access to findings and explanations based on facts, analysis, combination and evaluation of information. 


\section{THEORETICAL LITERATURE}

\section{Due to the nature of the study, the following framework is adopted}

\section{First: theoretical Literature}

The theoretical literature deals with two main axes, namely, the project-based learning strategy axis, and the critical thinking axis, as follows:

\section{The first axis: project-based learning strategy Concept of project-based learning strategy}

A project-based learning strategy is defined as a dynamic approach to teaching in which students discover real problems and challenges in the world around them, and at the same time, students acquire skills by working in small cooperative groups. Project-based learning is full of participation, positivity, and active learning, and provides students with deeper knowledge related to the subjects they study and consolidates the knowledge that the students have acquired by research compared to the information obtained by the traditional methods based on the instruction (Krauss \& Boss 2007 . (

Nabhan (2008) defines the project-based learning strategy as a unique learning method with a learnercentered focus. As for the teacher, his role is limited to supervising, directing, and assisting when needed. Students carry out self-activities under the supervision of the teacher. Omar (2010) also defines the projectbased learning strategy as any practical fieldwork carried out by the individual under the supervision of the teacher. It is also considered purposeful, serves the scientific material, and takes place in the appropriate environment.

\section{Stages of a project-based learning strategy:}

The project-based learning strategy goes through several stages:

\section{First: selecting a project}

Rail back (2002) believes that project selection is the most important stage of the project and the success of the project depends on it, and this step begins with the teacher raising a topic for discussion among students about a problem, difficulty or activity. Thus, the project shall stem from the needs and preferences of students, be suitable for students' level, lead to an abundant multi-faceted experience, take into account the individual differences between students when choosing a project, consider into account the diversity in the selected projects and take into account students' conditions and work potentials.

\section{Second: Project Planning}

Omar (2013) maintains that under the supervision of the teacher, students develop a plan for its implementation taking into account the following points such as determining the goals for the project, determining the type of individual or group activity required to achieve goals, determining the methods used to implement the activity, determining the timeframe for implementing the project and determining the project implementation stages and work requirements at each stage.

\section{Third: Implementation of the project}

Where the theoretical aspect is translated in light of the project plan into a concrete practical reality, the group members implement the action plan, which is the stage in which the plan and proposals move from the world of thinking and imagination into existence, where the students begin to move and work, and each of them performs the responsibility assigned to it. The teacher's role here is to create conditions, overcome difficulties, educational guidance, observe students during implementation, encourage them to work, meet with them to discuss some of the difficulties, and make adjustments in the topic if required (Posner and Applegrath, 2008).

\section{Fourth: Project Calendar}

The teacher evaluates the project in its final form, and students themselves may participate in the group evaluation process to see the product of his effort within the group effort. In evaluating the project, students review the work they have done and attained the benefits that accrue to them from this project. After the group 
evaluation process, a step of the project's steps can be repeated, or the whole project can be repeated in a better way so that they work to avoid previous mistakes (Lasheen, 2009).

\section{The role of the teacher and students in the project-based learning strategy}

Tawalbeh and Sarayra (2010) see the teacher's role in project-based learning strategy in showing the ability to analyze students' needs that reflect their interest, making good planning for events that help to achieve these needs, and proper implementation, and creating an attractive educational environment for students' learning motivations. This study adds other roles for the teacher, such as following up the students' implementation of the project steps, developing the spirit of the group and cooperation among the students by encouraging them to teamwork, verifying that each student does the work required, and not relying on others, and ensuring that students adhere to the project plan and not deviate from it unless circumstances arise that require reconsideration of the terms of the plan, where the teacher discusses the issue with students and agrees with them on the new amendments, and provides the materials and tools necessary to conduct the project in the vocational education workshop. Concerning the role of students, the project strategy emphasizes the important role of students, as they are the focus of the educational-learning process. Therefore, they are well-prepared to interact with life. The confidence in students' ability to excel and creativity in project implementation leads to preparing creative students.

\section{The second axis: critical thinking}

\section{The concept of critical thinking:}

Joseph Joseph (2008) defines it as the evaluation or judgment on proposed solutions to problems and issues, the ability of the individual to analyze, evaluate, conclude, and extrapolate to reach the causes and take appropriate decisions to take the right path. Abu Jadu and Nofal (2013) define it as the thinking that instills a spirit of inquiry and research and not accepting facts without investigation or definition, along with encouraging the practice of a range of thinking skills such as problem-solving, creative thinking, accurate comparison, discussion, originality, analysis, evaluation, conclusion, and decision-making. Critical thinking drives individuals to provide correct and acceptable explanations for the issues at hand, reduces false claims, and helps to monitor and control thinking, and take important decisions.

Sharaida (2008) inducates that the importance of critical thinking lies in making students more honest with themselves, and helping them to identify what is new, and not be afraid to confess mistakes because they can learn from their mistakes, as students will form their own beliefs, not what others decide and so they will be more independent, helping students to imagine themselves in the shoes of others, enabling them to understand the other points of view, developing the ability to listen to others with an open mind, even if their views differ, improving students' abilities to use their minds instead of their emotions, and enabling them to define their thoughts and logically link them with their emotions, working to develop better levels of their thinking among the students, considering at it as an entry point to reduce moral delinquency and the chance of crime because it prepares the individual with knowledge of justice, security and other concepts, and gaining a methodology in studying many subjects such as logic, literature, art, and history, so that the individual can evaluate and study them objectively.

\section{Critical thinking skills}

(Obaid and Afana, 2003; Atoum, Jarrah, and Beshara, 2007) mentioned four critical thinking skills, namely:

1. Knowledge of assumptions: it is the mental process by which an individual identifies assumptions included in the situations presented to him, or the ability to examine accidents or facts and judge them in light of the available data or evidence.

2. Evaluation of Arguments: it is the mental process by which the individual distinguishes between strong arguments and weak arguments based on their importance and relevance to the questions presented to him or the ability to distinguish between the strengths and weaknesses in judging a particular issue or incident in light of the available evidence.

3. Deduction: it is a mental process in which the individual arrives at a conclusion based on the presence of two logical introductions, or draws out the relationships among the facts given so that a judgment is made on the extent to which a result derived from those facts that are truly connected or not, regardless of the validity of the facts given or the attitude on them. 
4. Inference: it is the mental process by which an individual reaches certain conclusions with varying degrees of accuracy based on facts and data presented to him, and is the ability to distinguish between degrees of probability of correctness or error of a result, according to the degree of its relevance to certain facts given.

\section{Previous Studies}

Several studies have been written on critical thinking and learning strategies and processes.

Msallam (2015) verifies the effectiveness of the project-based learning method in improving the skills of critical appreciation of English poetry among female students of the English Language Department of the College of Education at Al-Azhar University in Gaza. The experimental one-group approach is used with a prepost application. The sample of the study consists of (40) students purposely selected from among (140) students from the English Language Department (Level Three), where the project-based learning method is used to improve the critical appreciation skills of English poetry. The study instrument consists of preparing a test to measure the four critical appreciation skills (reading, interpretation, analysis, and evaluation). The results of the study show that there is a statistically significant difference at the level of $(\alpha=0.05)$ in the performance of the study sample in the post-test in the skills of critical appreciation of English poetry due to the method of learning based on the project. In addition, Otaibi (2016) identifies a proposed model for projects based on participatory learning using social networks in developing critical thinking skills and self-efficacy among Princess Noura bint Abdul Rahman University students. To achieve the aims of the study, the semiexperimental approach is used. The study sample consists of (76) female students of the teacher of the primary grades at Princess Noura Bint Abdulrahman University, where (39) female students have represented the experimental group taught in the project learning course using the proposed model, and (37) female students have represented the control group taught in the traditional method of teaching. The study instruments are represented by the critical thinking test of Watson and Glaser, and the pre and post measure of self-efficacy of the study sample. The study shows that there are statistically significant differences at the level of $(\alpha=0.05)$ between the means of degrees of the experimental and control group in the critical thinking test and selfefficacy measure in favor of the experimental group.

Craig (2017) investigates the impact of a project-based learning strategy on developing critical thinking skills in the United States History Unit on eleventh-grade students at South Carolina State School. To achieve the objectives of the study, the quasi-experimental approach is used. The study sample consists of (31) male and female students, and it is distributed into an experimental group of (18) male and female students (8 males, 10 females), and a control group of (13) male and female students ( 3 males, 10 females). The study has used the following instruments: the California Critical Thinking Skills Test (CCTST) and the Cornell Z-level for the Critical Thinking Test (CLZ). The results of the study show that there is a statistically significant difference at the level of $(\alpha=0.05)$ between the pre and post measurement of critical thinking skills.

Mutlaq (2017) identifies the impact of project-based teaching in the Social and National Studies course on developing critical thinking skills among first-grade secondary students in Riyadh. To achieve the objectives of the study, the experimental approach is used with a quasi-experimental design. The study sample consists of (32) students, and it is distributed into experimental groups of (16) students, and a control group of (16) students. The study has used the following study instruments: the critical thinking skills test prepared by Watson and Glaser. The results show that there is a statistically significant difference at the level of $(\alpha=0.05)$ between the means of degrees of the experimental and control groups in the post-test in developing all critical thinking skills of first-grade secondary students in favor of the experimental group .

Mutawa (2018) identifies the effectiveness of the project-based learning strategy in developing critical thinking skills and academic achievement in mathematics among middle school students. To achieve the objectives of the study, the experimental approach is used with a quasi-experimental design on two control and experimental groups. The study sample consists of (63) female junior students divided into an experimental group of (32) students and a control group of (31) students. To measure the post-performance of the study groups, an achievement test and a test for critical thinking are prepared. The results show the superiority of the experimental group over the control group in the total degree of the achievement test and the superiority of the experimental group over the control group in the total degree of the critical thinking skill test.

However, the current study agrees with most of the previous studies in studying the impact of using project-based learning on developing critical thinking and in building the critical thinking test. Still, it disagrees with some studies using the Watson and Glaser test for critical thinking, and other studies using critical appreciation skills. Importantly, this study differs from some studies in dealing with other issues such as 
achievement and developing problem-solving skills. More importantly, the current study has benefited from previous studies in preparing theoretical literature, selecting the study sample, the research methodology, preparing the study tool, and interpreting and discussing the results. The current study is distinguished from previous studies by being one of the few studies aiming to identify the impact of using a project-based learning strategy on developing critical thinking skills among tenth-grade female students in the subject of vocational education in Jordan. It is also distinguished by its use of the type of applied construction and manufacturing projects that have targeted the production of yogurt, labneh, and white cheese.

\section{METHODOLOGY OF THE STUDY}

Due to the nature of the study, the study has used the experimental approach with a quasi-experimental design, as it suits the purposes of the study.

\section{Study Sample}

The study sample consists of the 10 $10^{\text {th }}$-grade female students at Rajm Al-Shami Al-Gharbi Mixed Secondary School from the Muwaqqar District. The simple random method is used in sorting and distributing the people by drawing lots among the tenth-grade classes (A, B, and C), where the (B) Division represents the control group taught using the traditional method and consists of (30) students, and Division (C) represents the experimental group taught using the project-based learning strategy and consists of (30) students.

\section{Study Instrument}

The Critical Thinking Test is prepared in its initial form of (21) multiple-choice items, as it consists of five questions on each of the following critical thinking skills (knowledge of assumptions, deduction, evaluation of arguments,) and six questions on the skill of deduction. The test is prepared through the Small Projects Unit (Dairy Processing) from the vocational education textbook for the tenth grade, which consists of the following topics (thermal treatments and sour milk manufacturing, sensory evaluation of Labneh, labneh manufacturing, sensory evaluation of yogurt, manufacturing white cheese, sensory evaluation of the white cheese. The test aims to identify the effect of teaching a vocational education subject using the project-based learning strategy on developing critical thinking skills among tenth-grade students. The test consists of measuring the following critical thinking skills: (knowledge of assumptions, deduction, inference, and evaluation of arguments) and critical thinking skills as a whole.

\section{Test's Validity and Reliability}

To verify the validity of the test, it is presented to a group of specialized validators to express their opinion on the suitability of the test items for critical thinking skills to ensure the language formation, the clarity of the test instructions, and to determine the level of test suitability for the level of tenth-grade students. Based on the opinions of the validators, some amendments are made such as the necessity of developing simplified and procedural definitions of critical thinking skills and supporting them with illustrative examples before starting the questions. After taking the opinions of the validators, the test is modified based on their observations, and the test has had an appropriate degree of apparent validity.

The validity of the test's internal consistency is also verified after applying it to a sample of (30) tenthgrade female students from outside the study sample. The correlation coefficient is calculated between the degrees of each of the test items and the total degree of the test as shown in Table (1).

Table 1. Correlation Coefficients between the Degree of Each Item of the Critical Thinking Test and the Total Degree

\begin{tabular}{|l|l|l|l|}
\hline Item & Correlation Coefficient & Item & Correlation Coefficient \\
\hline 1 & 0.59 & 12 & 0.39 \\
\hline 2 & 0.46 & 13 & 0.59 \\
\hline 3 & 0.67 & 14 & 0.41 \\
\hline 4 & 0.62 & 15 & 0.40 \\
\hline 5 & 0.44 & 16 & 0.83 \\
\hline 6 & 0.60 & 17 & 0.67 \\
\hline 7 & 0.67 & 18 & 0.37 \\
\hline
\end{tabular}




\begin{tabular}{|l|l|l|l|}
\hline 8 & 0.47 & 19 & 0.62 \\
\hline 9 & 0.55 & 20 & 0.39 \\
\hline 10 & 0.47 & 21 & 0.58 \\
\hline 11 & 0.53 & & \\
\hline
\end{tabular}

Table (1) shows that the values of the items' correlation coefficients with the total degree have ranged between (0.37-0.83), which are statistically acceptable values, indicating the validity of the test and its applicability to the study sample. To calculate the reliability of the test, it is applied to a sample of (30) students from the tenth grade who are not from the study sample. The reliability coefficients are calculated for each critical thinking skill and for the total test by using the Keoder-Richardson 20 (KR20) equation as shown in Table (2).

Table 2. The Reliability Coefficients for the Critical Thinking Skills and for the Total Test

\begin{tabular}{|l|l|}
\hline The Critical Thinking Skills & The Reliability Coefficients \\
\hline Knowledge of assumptions & 0.82 \\
\hline Evaluation of Arguments & 0.93 \\
\hline Deduction & 0.79 \\
\hline Inference & 0.93 \\
\hline Total Test & 0.96 \\
\hline
\end{tabular}

Table (2) shows that the total test's reliability coefficient is (0.96), which indicates acceptable reliability for the test, and the reliability coefficients for critical thinking skills have ranged between 0.79 0.93) which are acceptable reliability coefficients, reflecting the test's applicability and its skills with a good degree of reliability.

\section{Statistical Processing}

Due to the nature of the study, arithmetic means, standard deviations, Pearson Correlation Coefficient, t-test, and analysis of covariance (ANCOVA) test are used.

\section{RESULTS OF THE STUDY AND ITS DISCUSSION}

This section gives an insight into the questions of the study and its discussion.

Results related to the first question: What is the impact of using the project-based learning strategy in teaching vocational education on developing the skill of knowledge of assumptions among $10^{\text {th }}$-grade students compared to the traditional method?

To answer this question, the arithmetic means, standard deviations, and the adjusted arithmetic mean are calculated to compare the means of the degrees of the experimental and control groups in the postapplication of the critical thinking test in the skill of (knowledge of assumptions) as shown in Table (4)

Table 3. Arithmetic Means and Standard Deviations of Post-Performance and Adjusted Arithmetic Means of the Experimental and Control Groups in the Skill of Knowledge of Assumptions

\begin{tabular}{|l|l|l|l|l|l|}
\hline Skill & Group & Number & AM & SD & AAM \\
\hline Knowledge of & Experimental & 30 & 4.00 & 0.79 & 4.03 \\
\cline { 2 - 7 } Assumptions & Control & 30 & 3.57 & 1.04 & 3.54 \\
\hline
\end{tabular}

Table (3) shows an apparent difference between the means of the degrees of the experimental and control groups in the post-application of the test of critical thinking in the skill (knowledge of assumptions) in favor of the experimental group, where the arithmetic mean of the experimental group members is of (4.00), while the arithmetic means of the control group members are of (3.57). To demonstrate the significance of the statistical differences between the arithmetic means in the post-application according to the group variable (control experimental), after adjusting the pre-performance (accompanying variable), the analysis of covariance test (ANCOVA) is used as shown in (4). 
Table 4. The Results of the Analysis of Covariance (ANCOVA) for the Performance of the Study Sample in the Skill of Knowledge of the Assumptions in the Post Application According to the Difference of Groups

\begin{tabular}{|l|l|l|l|l|l|l|}
\hline $\begin{array}{l}\text { Source of } \\
\text { Variance }\end{array}$ & $\begin{array}{l}\text { Sum of } \\
\text { squares }\end{array}$ & $\begin{array}{l}\text { Degree of } \\
\text { freedom }\end{array}$ & $\begin{array}{l}\text { Mean of } \\
\text { squares }\end{array}$ & Value of F & $\begin{array}{l}\text { Level of } \\
\text { Significance }\end{array}$ & $\begin{array}{l}\text { Eta-square } \\
\text { Value }\end{array}$ \\
\hline Preperformance & 25.49 & 1 & 25.49 & 60.69 & .000 & \\
\hline Group & 3.60 & 1 & 3.60 & 8.57 & .000 & 0.13 \\
\hline Error & 23.88 & 57 & 0.42 & & & \\
\hline Total & 52.26 & 59 & & & & \\
\hline
\end{tabular}

Table (4) shows that there is a statistically significant difference at the level of statistical significance $(\alpha=0.05)$ in the post arithmetic means in the skill of knowledge of the assumptions due to the group (control - experimental) after adjusting the pre-performance. By referring to Table (4), it is noticed that the adjusted arithmetic mean of the experimental group is (4.03) versus (54.3) for the control group, indicating that the differences are in favor of the experimental group. Through the ETA square value for the skill of knowledge of assumptions, which amounted to (0.13), the effect size is considered medium according to Cohen's classification (2013), which indicates that the ETA square index is considered small when it equals (0.01), medium when it equals (0.06), and large when it is equal to (0.14). The size of the effect is $(13 \%)$ and explains (31\%) of the total variance in the post-performance, which is due to the use of the project-based learning strategy, and the rest equal to (87\%) is unexplained and attributed to other variables.

This result is explained by the fact that the use of the project-based learning strategy enhances the students' skill of knowledge of the assumptions through thinking-provoking questions in the introductory stage, project planning (explaining the theoretical framework), and presenting some of the manufacturing problems that may occur for dairy products during project implementation, research, and analysis to identify the causes of potential defects and errors of the final products and try to avoid them. In addition, the skill of knowledge of the assumptions requires careful analysis to identify the information, so the student creates during the implementation stages of the project many questions and assumptions, which she can answer through her exploratory and practical activities that support or refute those assumptions. This result is consistent with the results of (Yunis, 2011) and the study of (Mutawa, 2018), which shows the effectiveness of the project-based learning strategy and its role in developing students' critical thinking skills in the skill of knowledge of the assumptions.

Results to the second question: What is the impact of using the project-based learning strategy in teaching vocational education on developing the deduction skill of $10^{\text {th }}$ grade female students compared to the traditional method?

To answer this question, the arithmetic means, standard deviations, and the adjusted arithmetic mean are calculated to compare the means of the degrees of the experimental and control groups in the postapplication of the critical thinking test in the skill of (Deduction) as shown in Table (6)

Table 5. Arithmetic Means and Standard Deviations of Post-Performance and Adjusted Arithmetic Means of the Experimental and Control Groups in the Skill of Deduction

\begin{tabular}{|l|l|l|l|l|l|}
\hline Skill & Group & Number & AM & SD & AAM \\
\hline \multirow{2}{*}{ Deduction } & Experimental & 30 & 3.67 & 1.06 & 3.73 \\
\cline { 2 - 6 } & Control & 30 & 3.23 & 1.19 & 3.17 \\
\hline
\end{tabular}

Table (5) shows an apparent difference between the means of the degrees of the experimental and control groups in the post-application of the test of critical thinking in the skill of (deduction) in favor of the experimental group, where the arithmetic mean of the experimental group members id of (3.67), while the arithmetic means of the control group is of (3.23). ). To demonstrate the significance of the statistical difference between the arithmetic means in the post-application according to the group variable (control - experimental), after adjusting the pre-performance (the accompanying variable), the analysis of the covariance test (ANCOVA) is used as shown in Table (6). 
Table 6. The Results of the Analysis of Covariance (ANCOVA) for the Performance of the Study Sample in the Deduction Skill in the Post Application According to the difference of the Group

\begin{tabular}{|l|l|l|l|l|l|l|}
\hline $\begin{array}{l}\text { Source of } \\
\text { Variance }\end{array}$ & $\begin{array}{l}\text { Sum of } \\
\text { squares }\end{array}$ & $\begin{array}{l}\text { Degree of } \\
\text { freedom }\end{array}$ & $\begin{array}{l}\text { Mean of } \\
\text { squares }\end{array}$ & Value of F & $\begin{array}{l}\text { Level of } \\
\text { Significance }\end{array}$ & $\begin{array}{l}\text { Eta-square } \\
\text { Value }\end{array}$ \\
\hline Preperformance & 48.80 & 1 & 48.80 & 110.90 & .000 & \\
\hline Group & 4.61 & 1 & 4.61 & 10.47 & .000 & 0.16 \\
\hline Error & 25.23 & 57 & 0.44 & & & \\
\hline Total & 76.85 & 59 & & & & \\
\hline
\end{tabular}

Table (6) shows that there is a statistically significant difference at the level of statistical significance $(\alpha=0.05)$ in the post arithmetic means in the deduction skill attributed to the group (control - experimental) after controlling for the pre-performance. By referring to Table (6), it is noticed that the modified arithmetic mean of the experimental group is (3.73) versus (17.3) for the control group, indicating that the differences are in favor of the experimental group. Through the ETA square value of the deduction skill, which is (0.16), the size of the effect is considered large. It is explained that (16\%) of the total variance in the post-performance is due to the use of the project-based learning strategy, and the rest (84\%) is unexplained and attributed to other variable

This result is explained by the fact that the use of the project-based learning strategy enhances the deduction skill of the students using the method of dialogue and discussion, asking questions, and clarifying the results attained during the implementation and evaluation stage of the project. The use of activities and reports that the group is required to fill out during the project implementation stages develops the student's ability to make decisions and judge the result of the quality of dairy products. The result that is reached does not go beyond the limits of the given information, but to be reached, it is necessary to carefully consider, analyze and verify the information to obtain the correct results. This makes the student's ability to make better decisions based on the clarity of the picture and scrutinize the evidence and makes her thinking more effective in solving the emerging problems and incidents that she faces in her daily life. This result is consistent with the study of (Mutawa, 2018), which show that using a project-based learning strategy develops the induction skill, which is the ability to arrive at a conclusion based on the presence of information and logical introductions.

Results related to the third question: What is the impact of using the project-based learning strategy in teaching vocational education on developing the inference skill of 10th grade female students compared to the traditional method?

To answer this question, the arithmetic means, standard deviations, and the adjusted arithmetic mean are calculated to compare the means of the degrees of the experimental and control groups in the postapplication of the critical thinking test in the skill of (Inference) as shown in Table (7)

Table 7. Arithmetic Means and Standard Deviations of Post-Performance and Adjusted Arithmetic Means of the Experimental and Control Groups in the Skill of Inference

\begin{tabular}{|l|l|l|l|l|l|}
\hline Skill & Group & Number & AM & SD & AAM \\
\hline Inference & Experimental & 30 & 4.10 & 1.21 & 3.98 \\
\cline { 2 - 6 } & Control & 30 & 3.33 & 1.24 & 3.46 \\
\hline
\end{tabular}

Table (7) shows that there is an apparent difference between the means of the degrees of the experimental and control groups in the post-application of the critical thinking test in the skill (inference) in favor of the experimental group, where the arithmetic mean of the experimental group members is (4.10), while the arithmetic means of the control group members are (3.33). To demonstrate the significance of the statistical differences between the arithmetic means in the post-application according to the group variable (control experimental), after adjusting the pre-performance (the accompanying variable), the analysis of the covariance test (ANCOVA) is used as shown in table (8). 
Table 8. The Results of the Analysis of Covariance (ANCOVA) for the Performance of the Study Sample in the Inference Skill in the Post Application According to the difference of the Group

\begin{tabular}{|l|l|l|l|l|l|l|}
\hline $\begin{array}{l}\text { Source of } \\
\text { Variance }\end{array}$ & $\begin{array}{l}\text { Sum of } \\
\text { squares }\end{array}$ & $\begin{array}{l}\text { Degree of } \\
\text { freedom }\end{array}$ & $\begin{array}{l}\text { Mean of } \\
\text { squares }\end{array}$ & Value of F & $\begin{array}{l}\text { Level of } \\
\text { Significance }\end{array}$ & $\begin{array}{l}\text { Eta-square } \\
\text { Value }\end{array}$ \\
\hline Preperformance & 73.56 & 1 & 73.55 & 306.45 & .000 & \\
\hline Group & 4.04 & 1 & 4.04 & 16.80 & .000 & 0.23 \\
\hline Error & 13.81 & 57 & 0.24 & & & \\
\hline Total & 90.00 & 59 & & & & \\
\hline
\end{tabular}

Table (8) shows that there is a statistically significant difference at the level of statistical significance $(\alpha=0.05)$ in the post arithmetic means in the skill of inference attributed to the group (control - experimental) after controlling for the pre-performance. Concerning Table (7), it is noted that the adjusted arithmetic mean of the experimental group is (3.98) versus (3.46) for the control group, indicating that the differences are in favor of the experimental group. Through the ETA square value for inference skill, which amounted to (0.23), the size of the effect is considered large, and it is explained that (23\%) of the total variance in post-performance is due to the use of the project-based learning strategy, and the rest (77\%) is unexplained and attributed to other variables.

This result is explained by the fact that using the project-based learning strategy enhances the students 'inference skill by reviewing the students' previous information, adding to it during the project preparation and design processes, explaining the theoretical framework, drawing action steps, and developing hypotheses. The students build on the new practical experiences that enable them to reach and interpret the required results. Learning through practical activities during the implementation of the project phases helps students to observe and witness various facts and information. The observation of natural phenomena is considered as a broad vision that makes students more able to recall previous knowledge and relate it to the new situation. To reach and interpret the various inferences. Linking and generating ideas, dialogue, and collective participation between members of the same group or different groups for different activities or problems that may occur, increases their ability to evaluate discussions, increase their motivation towards learning, and reach the ability to judge the accuracy of the conclusions in terms of its correctness or incorrectness or lack of data for judgment. This result is consistent with the results of the study of (Mutawa, 2018), which show that the project-based learning strategy develops the skill of inference, which helps the students to distinguish between the degrees of probability of correctness or error of a result according to the facts and data provided to them.

Results related to the fourth question: What is the impact of using the project-based learning strategy in teaching vocational education on developing the skill of evaluation of arguments among 10th-grade students compared to the traditional method?

To answer this question, the arithmetic means, standard deviations, and the adjusted arithmetic mean are calculated to compare the means of the degrees of the experimental and control groups in the postapplication of the critical thinking test in the skill of (Evaluation of Arguments) as shown in Table (9)

Table 9. Arithmetic Means and Standard Deviations of Post-Performance and Adjusted Arithmetic Means of the Experimental and Control Groups in the Skill of Evaluation of Arguments

\begin{tabular}{|l|l|l|l|l|l|}
\hline Skill & Group & Number & AM & SD & AAM \\
\hline $\begin{array}{l}\text { Evaluation } \\
\text { Arguments }\end{array}$ & Experimental & 30 & 4.67 & 0.48 & 4.62 \\
\cline { 2 - 6 } & Control & 30 & 3.13 & 1.14 & 3.18 \\
\hline
\end{tabular}

Table (9) shows there is an apparent difference between the means of degrees of the experimental and control groups in the post-application of the critical thinking test in the skill (evaluation of arguments) in favor of the experimental group, where the arithmetic mean of the experimental group members is (4.67), while the arithmetic means of the control group members are (3.13). To demonstrate the significance of the statistical differences between the arithmetic means in the post-application according to the group variable (control experimental), after adjusting the pre-performance (the accompanying variable), the analysis of covariance test (ANCOVA) is used as shown in Table (10). 
Table 10. The Results of the Analysis of Covariance (ANCOVA) for the Performance of the Study Sample in the Evaluation of Arguments Skill in the Post Application According to the difference of the Group

\begin{tabular}{|l|l|l|l|l|l|l|}
\hline $\begin{array}{l}\text { Source of } \\
\text { Variance }\end{array}$ & $\begin{array}{l}\text { Sum of } \\
\text { squares }\end{array}$ & $\begin{array}{l}\text { Degree of } \\
\text { freedom }\end{array}$ & $\begin{array}{l}\text { Mean of } \\
\text { squares }\end{array}$ & Value of F & $\begin{array}{l}\text { Level of } \\
\text { Significance }\end{array}$ & $\begin{array}{l}\text { Eta-square } \\
\text { Value }\end{array}$ \\
\hline Preperformance & 9.81 & 1 & 9.81 & 16.35 & .000 & \\
\hline Group & 31.11 & 1 & 31.11 & 51.85 & .000 & 0.48 \\
\hline Error & 34.32 & 57 & 0.60 & & & \\
\hline Total & 75.24 & 59 & & & & \\
\hline
\end{tabular}

Table (10) shows there is a statistically significant difference at the level of statistical significance $(\alpha=$ 0.05 ) in the post arithmetic means in the skill of evaluation of arguments attributed to the group (control experimental) after controlling for the pre-performance. By referring to Table (9), it is noticed that the adjusted arithmetic mean of the experimental group is (4.62) versus (3.18) for the control group, indicating that the differences are in favor of the experimental group. With the ETA square value of the evaluation of arguments skill (0.048), the size of the effect is large. It is explained that (48\%) of the total variance in the postperformance is due to the use of the project-based learning strategy, and the rest (52\%) is unexplained and attributed to other variables.

This result is explained by the fact that the use of the project-based learning strategy enhances the skills of evaluation of the arguments of the students through the practical application of activities and steps during the implementation of the project, and dialogue and discussion within the same group or with other groups, which may encourage students to participate in effective critical practices, including listening and research for a solution or conclusion, which gives rise to different opinions. Providing a participatory work environment in which female students feel safe and comfortable provides an opportunity for dialogue, discussion, criticism, and the exchange of opinions objectively and fairly, and it gives students the skill to evaluate evidence and argume

This result is consistent with the results of the study of (Mutawa, 2018) that the project-based learning strategy develops the skill of evaluation of arguments among tenth-grade students, and makes them able to distinguish between strengths and weaknesses in judging the information contained in the project.

Results related to the fifth question: What is the impact of using the project-based learning strategy in teaching vocational education on developing critical thinking skills as a whole among the 10th-grade female students compared to the traditional method?

To answer this question, the arithmetic means, standard deviations, and the adjusted arithmetic mean are calculated to compare the means of the degrees of the experimental and control groups in the post-application of the critical thinking test as a whole as shown in Table (11)

Table 11. Arithmetic Means and Standard Deviations of Post Performance and Adjusted Arithmetic Means of the Experimental and Control Groups in the Skill of the Critical Thinking as a Whole

\begin{tabular}{|l|l|l|l|l|l|}
\hline Skill & Group & Number & AM & SD & AAM \\
\hline $\begin{array}{l}\text { Skill of the } \\
\begin{array}{l}\text { Critical } \\
\text { Thinking as a } \\
\text { Whole }\end{array}\end{array}$ & Control & 30 & 20.60 & 2.28 & 20.57 \\
\cline { 2 - 6 } & & 16.27 & 2.49 & 16.30 \\
\hline
\end{tabular}

Table (11) shows that there is an apparent difference between the means of the degrees of the experimental and control groups in the post-application of the critical thinking test for critical thinking skills as a whole in favor of the experimental group, where the arithmetic mean of the experimental group members is (20.60), while the arithmetic means of the control group are (16.27). To demonstrate the significance of the statistical differences between the arithmetic means in the post-application according to the group variable (control - experimental), after adjusting the pre-performance (the accompanying variable), the analysis of covariance test (ANCOVA) is used as shown in Table (12). 
Table 12. The Results of the Analysis of Covariance (ANCOVA) for the Performance of the Study Sample in the Skill of the Critical Thinking as a Whole in the Post Application According to the difference of the Group

\begin{tabular}{|l|l|l|l|l|l|l|}
\hline $\begin{array}{l}\text { Source of } \\
\text { Variance }\end{array}$ & $\begin{array}{l}\text { Sum of } \\
\text { squares }\end{array}$ & $\begin{array}{l}\text { Degree of } \\
\text { freedom }\end{array}$ & $\begin{array}{l}\text { Mean of } \\
\text { squares }\end{array}$ & Value of F & $\begin{array}{l}\text { Level of } \\
\text { Significance }\end{array}$ & $\begin{array}{l}\text { Eta-square } \\
\text { Value }\end{array}$ \\
\hline Preperformance & 211.28 & 1 & 211.28 & 100.60 & .000 & \\
\hline Group & 273.62 & 1 & 273.62 & 130.29 & .000 & 0.70 \\
\hline Error & 119.79 & 57 & 2.10 & & & \\
\hline Total & 604.69 & 59 & & & & \\
\hline
\end{tabular}

Table (12) shows that there is a statistically significant difference at the level of statistical significance $(\alpha=$ 0.05 ) in the post arithmetic averages in critical thinking skills as a whole attributed to the group (control experimental) after controlling for the pre-performance. By referring to Table (11), it is noticed that the adjusted arithmetic means for the experimental group are (20.57) versus (16.30) for the control group, indicating that the differences are in favor of the experimental group. With the ETA square value for critical thinking skills as a whole that is (0.70), the size of the effect is considered large. It is explained that (70\%) of the total variance in the post-performance is due to the use of the project-based learning strategy, and the rest $(30 \%)$ is unexplained and attributed to other variables.

This result is explained by the fact that the use of the project-based learning strategy enhances the total critical thinking skills of the students through the participation of the students in the preparation and implementation of the project phases (project selection, design, implementation, and evaluation). Providing a participatory work environment that provides a positive and structured learning environment, where students and the teacher participate in the discussion, dialogue, criticism, and exchange of views gives students the skills of the ability to deduce, infer, and identify assumptions. In addition, dealing with a realistic environment and exposure to experience directly helps to search and explore, obtain information, exchange knowledge, and develop accuracy in observing facts and events, alongside developing critical thinking skills through objective examination and criticism, and freedom of expression in the perceptual evaluation of the products of various projects through the observation tool. Motivation and encouragement have a great role in increasing the demand for classroom learning, various classroom situations, and experiences, and increases the students' vitality in organizing experiences and safely interacting with them under the supervision and guidance of the teacher. Project-based teaching also provides female students with the opportunity to self-learn and build knowledge in an atmosphere of psychological security, intellectual freedom, democracy, tolerance, and acceptance, which leads to the development of their critical thinking. This result is consistent with the results of the study of (Msallam, 2015), and the study of Craig of (2017), which show that using a project-based learning strategy develops critical thinking skills as a whole by achieving a positive learning environment that provides factors of excitement and attraction and provides the student with an opportunity to building knowledge and self-learning.

\section{RECOMMENDATIONS}

In light of the previously mentioned results, several recommendations are made such as adopting the projectbased learning strategy as a basic strategy in teaching most units of the vocational education subject for its suitability for most of the activities in the units of the book. training male and female teachers on project-based learning strategy, and how to practice critical thinking in teaching vocational education, through training programs and modeling, organizing an exhibition for the products of the students 'projects in the subject of vocational education and marketing, and Knowing the impact of the project method on other variables, such as creative thinking, decision-making ability, trends, and personal characteristics.

\section{ACKNOWLEDGEMENT}

The authors are grateful to the Middle Eat University, Amman, Jordan for the financial support granted to cover the publication fees of this research article. 


\section{REFERENCES}

Abu Al-Haija, F.(2001). Teaching basics skills and general methods. Amman: House of Approaches for Publishing and Distribution.

Abu Jadu, S., \& Nofal, M.(2013). Teaching theoretical and practical thinking. Amman: House of the March .

Atoum, A., Jarrah, A., \& Beshara, M.(2007). Development of thinking skills. Amman: Dar AlMasirah.

Aziz, M.(2005). Thinking from an educational perspective. Cairo: The World of Books.

Boss, S., \& Krauss, J.(2007). Reinventing project-based learning: Your field guide to real- world projects in the digital age," ( 2 nd Ed.).Washington: International Society for Technology in Education.

Cohen, J.(2013). Statistical power analysis for the behavioral sciences (Rev.ed.). New York: Academic press.

Craig, C. E.(2017). Impact of project-based learning on critical thinking in a United States history classroom, (Doctoral dissertation). University of South Carolina, USA.

Ebeid, W., \& Afana, E.(2003). Thinking and the school curriculum. Kuwait: Falah Library for Publishing and Distribution.

Fatlawi, S.(2004). Unique education in teacher preparation and qualification is a model for measurement and evaluation. Amman: Dar Shorou.

Hariri, R.(2020). Teaching methods between tradition and renewal. Amman: House of Thoug.

Joseph, Q.I.(2008). Influence of teaching styles and peer collaborative on science and math learning, (doctoral dissertation), Washington State University, USA.

Khamis, F., \& Abu Hammoud, H.(2018). Reality of teaching the vocational education course in the basic education stage from the viewpoint of course teachers and workshop secretaries in the official schools of the Lattakia governorate. Studies and Educational Sciences Journal, 45 (2), 135-162.

Lashin, S. A.(2009). Effectiveness of the project-based learning strategy model in developing self-organization skills and academic performance in mathematics. The Egyptian Association for Curricula and Teaching Methods, 1(51), 135-167.

Mahasneh, O.(2013). Professional education curricula, teaching and evaluation strategies. Amman: House of the world of culture for publishing and distribution.

Mahasneh, O., \& Azmi, A.(2015). Effect of using a modern workshop method for the five-group groups on the achievement of the tenth basic students in vocational education. Studies and Educational Sciences Journal, 42 (1), 1-11.

Mariee, T., \& Haila, M.(2009). General Teaching Methods. Dar Al-Masirah: Amman.

Msallam, H., M.(2015). The effectiveness of using PBL in poetry classes on enhancing critical appreciation skills among EFL majors at AUG, (Master Thesis), Al-Azhar University, Gaza.

Mutawa, I.(2018). "Effectiveness of Project-Based Learning Strategy in Developing Critical Thinking Skills and Academic Achievement in Mathematics for Middle School Students. The Educational Journal, 32(126), 169-227

Nabhan, Y.(2008).Modern methods of teaching and learning. Amman: Al-Yazwi House for Publishing and Distribution.

Odeh, A.(2010). Measurement and evaluation in the teaching process. Dar Al-Amal, Irbid, Jordan.

Omar, A., \& Nasreddin, S.(2013). " A proposed envision for employing social networks in project-based learning and its impact on increasing achievement motivation and the trend towards learning via the web." The third international conference on e-learning and distance learning, Riyadh, SA.

Omar, I.(2010). Teaching Methods. House of Culture for Publishing and Distribution, Amman, Jordan, 2010.

Otaibi, W.(2016). Effectiveness of a suggested model for project learning based on participatory learning using social networks in developing critical thinking skills and self-efficacy of Princess Noura Bint Abdul Rahman University Students. Journal of Educational and Psychological Studies, 10(3), 561-576.

Posner, K.(2008). Project management Pocketbook, (2 ${ }^{\text {nd }}$ Ed). UK: Management Pocketbook Ltd.

Railback, J.(2002). Project-based learning Instruction: creating excitement for Learning, (1 ${ }^{\text {st }}$ Ed.). Washington, Northwest Regional Education Laboratory.

Saeedi, A., \& Balushi, S.(2008). Methods of teaching science concepts and practical applications. Amman: House of the March.

Shuraida, M., K.(2003). Effect of a metacognitive training program on the critical thinking of university students and its relationship to some variables, [Unpublished PhD Thesis], Amman Arab University for Graduate Studies, Amman, Jordan. 
Tawalbeh, H., \& Sarayra, B.(2010). Teaching methods. Amman: House of the March.

Yunis, W.(2011). Effect of using the project method on the achievement of second grade students in the teacher preparation institute in biology and the development of their critical thinking skills. Journal of Education and Science, 18(3), 323-359.

Zaitoun, A.(2007). Constructivist theory and teaching strategies. Amman: Dar Shorouk.

Zaitoun, H.(2003). Teaching thinking. Cairo: The World of Book.

Zoubi, R.(2014). Critical thinking: Specialized professional development program for teachers, teaching and learning in the classroom, Trainee's Handbook, 71-72. 